Perinatology pISSN 2508-4887 • elSSN 2508-4895
Original article

Perinatology Vol. 30, No. 3, September, 2019

https://doi.org/10.14734/PN.2019.30.3.117

\title{
SYM 2081 Exerts Neuroprotective Effect Modulating Anti-Apoptosis in the Hypoxic- Ischemic Brain Injury of Neonatal Rats
}

\section{Jin Kyung Park, MD', Yoon Young Jang, MD', Ji Eun Jeong, MD', Eun Joo Lee, $M D^{2}$, Eun Jin Choi MD', Hai Lee Chung, MD', Woo Taek Kim, MD ${ }^{1}$}

'Department of Pediatrics, Catholic University of Daegu School of Medicine, Daegu; 'Department of Pediatrics, Kyungpook National University School of Medicine, Daegu, Korea
Received: 18 July 2018

Revised: 19 September 2018

Accepted: 18 April 2019

Correspondence to

Woo Taek Kim, MD

Division of Neonatology, Department of Pediatrics, Catholic University of Daegu School of Medicine, 33 Duryugongwon-ro 17-gil, Nam-gu, Daegu 42472, Korea

Tel: +82-53-650-4250

Fax: +82-53-622-4240

E-mail:wootykim@hanmail.net

Copyright@ 2019 by The Korean Society of Perinatology

This is an Open Access article distributed under the terms of the Creative Commons Attribution Non-Commercial License (http://creativecommons.org/ license/by-nc/4.0/), which permits unrestricted non-commercial use, distribution, and reproduction in any medium, provided that the original work is properly cited.
Objective: SYM 2081 ((2S,4R)-4-methylglutamic acid), an agonist and functional antagonist of the kainite receptor, has shown a neuroprotective effect in neurodegenerative diseases in adults but little is known concerning perinatal hypoxic-ischemic encephalopathy. This study is designed to evaluate whether SYM 2081 has preventive mechanisms via anti-apoptosis to gain further insight into neuroprotective roles of SYM 2081.

Methods: In an in vivo animal model, the left carotid artery was ligated in 7-day-old Sprague-Dawley rat pups. The pups were divided into six groups: normoxia (N), hypoxia $\left(8 \% \mathrm{O}_{2}, 92 \% \mathrm{~N}_{2}\right)(\mathrm{H})$, H with shamoperation, $\mathrm{H}$ with operation (HO), $\mathrm{HO}$ treated with vehicle and $\mathrm{HO}$ treated with SYM 2081. In an in vitro model, the cultured embryonic cortical neuronal cells were divided into three groups: normoxia (95\% air, $\left.5 \% \mathrm{CO}_{2}\right)$, hypoxia $\left(94 \% \mathrm{~N}_{2}, 5 \% \mathrm{CO}_{2}\right)(\mathrm{Hc})$, and Hc treated with SYM 2081 before a hypoxic insult. Apoptosis was assessed using western blots and real-time polymerase chain reaction with $\mathrm{BCl}-2$, Bax, and caspase- 3 antibodies and mRNAs.

Results: In both in vitro and in vivo studies, Bcl-2 expression increased, whereas expressions of Bax, caspase-3, and the ratio of Bax/BCl-2 were reduced with SYM 2081 treatment resulting in improved cell survival.

Conclusion: This study showed that SYM 2081 exerts a neuroprotective effect against hypoxic-ischemic injury through modulating apoptotic signaling pathways.

Key Words: 4-methylglutamic acid, Hypoxia-ischemia, Brain, Apoptosis

\section{Introduction}

Hypoxic-ischemic encephalopathy (HIE) is a leading cause of major mortality and morbidity in the neonatal period. ${ }^{1,2}$ Hypothermia is now used as an established therapy, but many newborns with moderate to severe HIE still suffer from severe neurodevelopmental problems. ${ }^{2,3}$ Thus, continuous efforts have been conducted to benefit from adjuvant therapy in combination with hypothermia treatment. ${ }^{1}$ Understanding of the cellular signaling network that regulates programmed cell death and identification of the genes can provide insights for therapies targeted at inhibition of cell death after neonatal HIE.

Apoptosis is one important mechanism controlling the neuronal damage after hypoxicischemic (HI) injury. ${ }^{4}$ Caspase-related signaling pathways can lead to apoptosis and are likely involved in neurodegeneration. ${ }^{5,6}$ Apoptosis is regulated by a balance between the pro- and anti-apoptotic proteins. ${ }^{5,8}$ Expression of several apoptosis-associated proteins is induced by brain damage. ${ }^{9}$ The classic pathways associated with caspase activation, each with distinct molecular mechanisms, are the caspase-9-dependent intrinsic and the caspase-8-dependent extrinsic pathways. ${ }^{10}$ The caspase -3 pathway is common to both final intrinsic and extrinsic pathways for apoptosis and thus has been used as a marker for assessing apoptosis. ${ }^{11} \mathrm{The} \mathrm{Bcl}$ family members are also activated following neonatal $\mathrm{HI}$ injury and are closely related to the 
intrinsic pathways for apoptosis. As apoptosis after neonatal HI injury is known to be caspase-dependent, inhibitors of caspases could defend cells against $\mathrm{HI}$ injury. ${ }^{12}$

Several reports demonstrated the associations between glutamate receptors and excitotoxicity. ${ }^{13,14}$ Kainate receptor (KAR) has also been known to contribute to excitotoxicity with N-methyl-D-aspartate (NMDA) or a-amino-3-hydroxy-5methyl-4-isoxazolepropionic acid (AMPA) receptors. ${ }^{15} \mathrm{Al}^{-}$ though KAR has various functions such as regulation of glutamate release, inhibition of GABA release, and induction of calcium current in the presence of an agonist, it has been shown that its various responses depend on factors such as subtype, editing, location, maturation, and agonist concentration. ${ }^{16,17} \mathrm{Re}^{-}$ search on KAR has been less frequent than for other glutamamergic receptors.

Our previous study showed the neuroprotective effect of SYM 2081 ((2S,4R)-4-methylglutamic acid) through modulating KAR expression in neonatal rat brain. ${ }^{18}$ This raised our interest in investigating the possible cellular mechanisms of SYM 2081 effects on gene expression of apoptosis. Therefore, this study is designed to evaluate whether SYM 2081 has preventive mechanisms via anti-apoptosis using western blots and real-time PCR with Bcl-2, Bax, and caspase-3 antibodies and mRNAs to gain further insight into neuroprotective roles of SYM 2081.

\section{Methods}

\section{Materials}

We purchased SYM 2081 from Tocris (Bristol, UK). Primary antibodies used in this study included the following: $\mathrm{Bcl}-2$ (1:1,000; Santa Cruz Biotechnology, Dallas, TX, USA), Bax (1:1,000; Cell Signaling Technology, Danvers, MA, USA), caspase-3 (1:1,000; Cell Signaling Technology), and $\beta$-Actin (1:1,000; Santa Cruz Biotechnology). Secondary antibodies used were goat anti-mouse or rabbit IgG-HRP (1:2,000; Santa Cruz Biotechnology).

\section{Animal model and drug administration}

This study was carried out under the approved animal use guidelines and protocol of the Catholic University of Daegu. All rats were supplied with food and water ad libitum and were housed at $23 \pm 1^{\circ} \mathrm{C}$ on a $12: 12-\mathrm{h}$ light:dark cycle. The rat pups were reared with their respective mothers. Experiments were performed on postnatal seven-day-old Sprague-Dawley (SD) rat pups in this research. To induce perinatal $\mathrm{HI}$ brain injury, a modification of the Levine preparation was used as a model for perinatal $\mathrm{HI}$ brain injury as previously described. ${ }^{19}$ Briefly, the left carotid artery (LCCA) was isolated via midline incision at the longitudinal plane under isoflurane anesthesia and underwent double ligation permanently with 5-0 surgical silk. The total period of procedure never exceeded 5 minutes. Following one hour of recovery with the dam and feeding, the pups were placed in an airtight polypropylene container $(295 \times 230 \times 84 \mathrm{~mm}, 3.9 \mathrm{~L}$ volume; Lock \& Lock, Yongin, Korea), which were submerged in a $37^{\circ} \mathrm{C}$ water bath and exposed to hypoxia (a mixture of $8 \% \mathrm{O}_{2}$ and $92 \% \mathrm{~N}_{2}$ ) for 2 hours. The oxygen level was monitored using an oxygen monitor (Hudson RCI, Temecula, CA, USA). After this hypoxic exposure, the pups were returned to their dams for the indicated time. As the test agent, SYM 2081 was dissolved in phosphate-buffered saline (PBS) and injected intraperitoneally (i.p.) at a dose of $10 \mathrm{mg} / \mathrm{kg}$ at 30 minutes before the hypoxic exposure. We used the dose of a previous study that showed neuroprotective effects. ${ }^{18}$

Over the course of the experiment, a total of 55 litters were under study from which six rats died. The animals were randomly divided into six groups ( $\mathrm{n}=7-10$ /group). The animals were randomly allocated into six treatment groups: normoxia (N, n=8) was not exposed to hypoxia; hypoxia $(\mathrm{H}, \mathrm{n}=8)$ was exposed to hypoxia without operation; $\mathrm{H}$ with Sham-operation (HS, n=9) was subjected to open-close surgery but not to LCCA ligation; $\mathrm{H}$ with an operation ( $\mathrm{HO}, \mathrm{n}=7$ ) was subjected to LCCA ligation and hypoxia. HO treated with vehicle (HV, $\mathrm{n}=9$ ) was injected with PBS (the same volume as that of SYM 2081); and HO treated with SYM 2081 (HM, n=8) was injected systemically with $10 \mathrm{mg} / \mathrm{kg}$ of SYM 2081 at 30 minutes before a hypoxic insult.

Pups from each litter were randomly assigned and marked to $\mathrm{N}, \mathrm{H}, \mathrm{HS}, \mathrm{HO}, \mathrm{HV}$, and HM groups. The experiments were repeated four times $(n=4)$ in the western blots and six times $(n=6)$ in the real-time PCRs.

\section{Embryonic cortical neuronal cell culture of rats}

In the second set of experiments, cultures of dissociated 
cortical neuronal cells were prepared from SD rat embryos pregnant for 19 days using methods similar to those previously described. ${ }^{20}$ The fetal pups were washed in $100 \%$ ethanol and Hanks' balanced salt solution (HBSS) (GibcoBRL, Grand Island, NY, USA). Briefly, cerebral cortices were separated and dissected at $37^{\circ} \mathrm{C}$ in HBSS containing $1 \mathrm{mM}$ sodium pyruvate and $10 \mathrm{mM}$ (4-(2-hydroxyethyl)-1-piperazineethanesulfonic acid (pH 7.4). The dissected brain cortical tissues were then placed in $2 \mathrm{~mL}$ of trypsin and incubated at $37^{\circ} \mathrm{C}$ in a water bath for 1 minute. After washing with $10 \mathrm{~mL}$ of HBSS, the cell suspension was centrifuged at 1,000 rpm at $25^{\circ} \mathrm{C}$ for 5 minutes and the pellets washed with HBSS (without phenol red). Cells were plated at approximately $2 \times 10^{6}$ cells $/ \mathrm{mm}^{2}$ in each dish. Cells were cultured in Neurobasal media (GibcoBRL) (100 mL neurobasal, 2\% B27 supplement, $0.25 \mathrm{~mL}$ glutamax I, $0.1 \mathrm{~mL} 25 \mathrm{mM}$ glutamate, $0.1 \mathrm{~mL} 25 \mathrm{mM} 2$-mercaptoethanol) in a $\mathrm{CO}_{2}$ chamber. A fifth of the medium was replaced with fresh feeding Neurobasal media (GibcoBRL) (100 mL neurobasal, 2\% B27 supplement, $0.25 \mathrm{~mL}$ glutamax I) every three days.

The cultured cells were randomly allocated into three groups: normoxia (Nc); hypoxia (Hc); and hypoxia treated with SYM 2081 (HMc). The Nc group was prepared in $5 \% \mathrm{CO}_{2}$ incubators and the other groups (before a hypoxia injury) in $1 \% \mathrm{O}_{2}$ incuba- $^{-}$ tors $\left(94 \% \mathrm{~N}_{2}, 5 \% \mathrm{CO}_{2}\right)$ for 16 hours. The Nc group served as controls. The experiments were repeated four times $(n=4)$ in the western blots and six times $(n=6)$ in the real-time PCRs.

\section{Brain extraction and protein isolation}

Rat pups were sacrificed on the seventh day after the hypoxic insult (on post-natal day 14). Brain samples were rapidly removed from the left cerebral hemispheres and then homogenized in a protein lysis buffer (Complete protease inhibitor cocktail tablets [Roche Applied Science, Mannheim, Germany]), $1 \mathrm{M}$ Tris- $\mathrm{HCl}$ (pH 8.0), $5 \mathrm{M} \mathrm{NaCl}, 10 \%$ Nonidet P-40, and $1 \mathrm{M}$ 1,4-dithio-DL-threitol (DTT) for 20 minutes on ice. This homogenate was subjected to centrifugation at $12,000 \mathrm{rpm}$ at $4^{\circ} \mathrm{C}$ for 30 minutes, and the supernatant was transferred to a new tube for analysis. The total protein was measured with a Bio-Rad Bradford Kit (Bio-rad Laboratories, Hercules, CA, USA).

\section{Western blotting}

Approximately $50 \mu \mathrm{g}$ of the total protein was denatured in a sodium dodecyl sulfate (SDS) gel-loading buffer (100 mM TrisHCl [pH 6.8], 200 mM DTT, 20\% glycerol, 4\% SDS and 0.2\% bromophenol blue) in boiling water for 10 minutes. Samples of equal protein amounts underwent a $12 \%$ SDS-polyacrylamide gel electrophoresis (SDS-PAGE). The separated protein samples were then electrophoretically transferred onto a polyvinylidene difluoride membrane (Millipore, Billerica, MA, USA) at a constant voltage of $10 \mathrm{~V}$ for 30 minutes. The membrane was blocked in $5 \%$ skim milk in tris-buffered saline/0.1\% tween-20 (TBST) for 1 hour at room temperature, and then incubated overnight in $5 \%$ skim milk/TBST with the primary antibodies at $4^{\circ} \mathrm{C}$. After washing the membrane blots, they were incubated with the secondary antibodies (1:2,000 dilution) at room temperature for 1 hour, and the signal was developed using an enhanced chemiluminescence Plus Western Blotting Detection System (Amersham Biosciences, Piscataway, NJ, USA) or SUPEX (Neuronex, Pohang, Korea). The intensity of the corresponding western blot band was measured by using a densitometer (Multi Gauge Software; Fuji Photofilm, Tokyo, Japan).

\section{RNA extraction and real-time PCR}

Tissues and cells were homogenized in TRIzol reagent (Invitrogen Corporation, Carlsbad, CA, USA) before a 5 minutes incubation at room temperature followed by a chloroform treatment $(200 \mu \mathrm{L})$ for dissociation of the nucleoprotein complexes. The sample tubes were shaken by hand for 15 seconds, and incubated at room temperature for 2 minutes. The upper aqueous RNA phase was collected following centrifugation $(12,000 \mathrm{xg}$ for 15 minutes at $4^{\circ} \mathrm{C}$ ). The aqueous phase was then transferred into a fresh tube and precipitated into a gel-like pellet with $500 \mu \mathrm{L}$ isopropyl alcohol by incubating for 10 minutes at room temperature and then centrifuging $\left(12,000 \mathrm{x}\right.$ g for 15 minutes at $\left.4^{\circ} \mathrm{C}\right)$. After removal of the supernatant, the RNA pellet was washed once with $1 \mathrm{~mL} 75 \%$ ethanol by centrifugation (7,500 $\mathrm{x}$ g for 5 minutes at $4^{\circ} \mathrm{C}$ ). The RNA pellet was air-dried for 10 minutes before redissolving the RNA in $100 \mu \mathrm{L}$ RNase-free water and incubating for 10 minutes at $60^{\circ} \mathrm{C}$. The amount and purity of extracted RNA were quantitated by a GeneQuant 1,300 spectrophotometer (GeneQuant ${ }^{\mathrm{TM}}$ proRNA/DNAcalculator, GEHealthcare, Logan, UT, USA) and the RNA was stored at $-70^{\circ} \mathrm{C}$ before further processing. For the real-time PCR (For reverse transcription), the total RNA [1 $\mu$ g] was reverse transcribed for 
1 hour at $37^{\circ} \mathrm{C}$ in a reaction mixture containing $20 \mathrm{U}$ RNase inhibitor (Promega, Madison, WI, USA), 1 mM dNTP (Promega), 0.5 ng Oligo 15 primer (Promega), 1x RT buffer and 200 U MMLV reverse transcriptase (Promega). The reaction mixture was then incubated at $95^{\circ} \mathrm{C}$ for 5 minutes to stop the reaction and the cDNA was stored at $-20^{\circ} \mathrm{C}$ for further processing.

A real-time PCR was carried out in a $20 \mu \mathrm{L}$ volume with $10 \mu \mathrm{L}$ of kit-supplied $\mathrm{iQ}^{\mathrm{TM}}$ SYBR Green Supermix (Bio-rad Labora-

\section{Table 1. Primer Pairs and Annealing Temperature for Real-Time PCR}

\begin{tabular}{llc}
\hline Name & \multicolumn{1}{c}{ Primer sequence (5'-3') } & Annealing \\
\hline BCl-2 & F:TTGACGCTCTCCACACACATG & $57^{\circ} \mathrm{C}$ \\
& R:GGTGGAGGACTCTTCAGGGA & \\
Bax & F:TGCTGATGGCAACTTCAACT & $55^{\circ} \mathrm{C}$ \\
& R:ATGATGGTTCTGATCAGCTCG & \\
Caspase-3 & F:AATTCAAGGGACGGGTCATG & $56^{\circ} \mathrm{C}$ \\
& R:GCTTGTGCGCGTACAGTTC & \\
\hline
\end{tabular}

Abbreviation: $P C R$, polymerase chain reaction. tories), $1 \mu \mathrm{L}$ ( $2 \mathrm{pmol}$ ) of each primer, $7 \mu \mathrm{L}$ RNase-free water, $1 \mu \mathrm{L}$ cDNA. The amplification was performed in 48 well PCR plates (Mini Opticon ${ }^{\mathrm{TM}}$ Real-Time PCR System; Bio-rad Laboratories) with an initial denaturation for 5 minutes at $95^{\circ} \mathrm{C}$, followed by 40 cycles of denaturation for 30 seconds at $95^{\circ} \mathrm{C}$, annealing for 30 seconds at room temperature, extension for 30 seconds at $72^{\circ} \mathrm{C}$, and a final extension for 10 minutes at $72^{\circ} \mathrm{C}$. The primer sequences are indicated in Table 1 . The real-time PCR data were analyzed with LightCycler software (Bio-rad Laboratories) and then determined using the $2^{-\Delta \Delta \mathrm{Ct}}$ method described by Livak \& Schmittgen. ${ }^{21}$ The relative amounts of mRNA were normalized by $\beta$-actin and calculated from the $\mathrm{Ct}$ values according to the manufacturer's description. The procedures were sextuplicated for each experiment.

\section{Statistics analysis}

Data analysis was performed using SPSS version 22 statistical
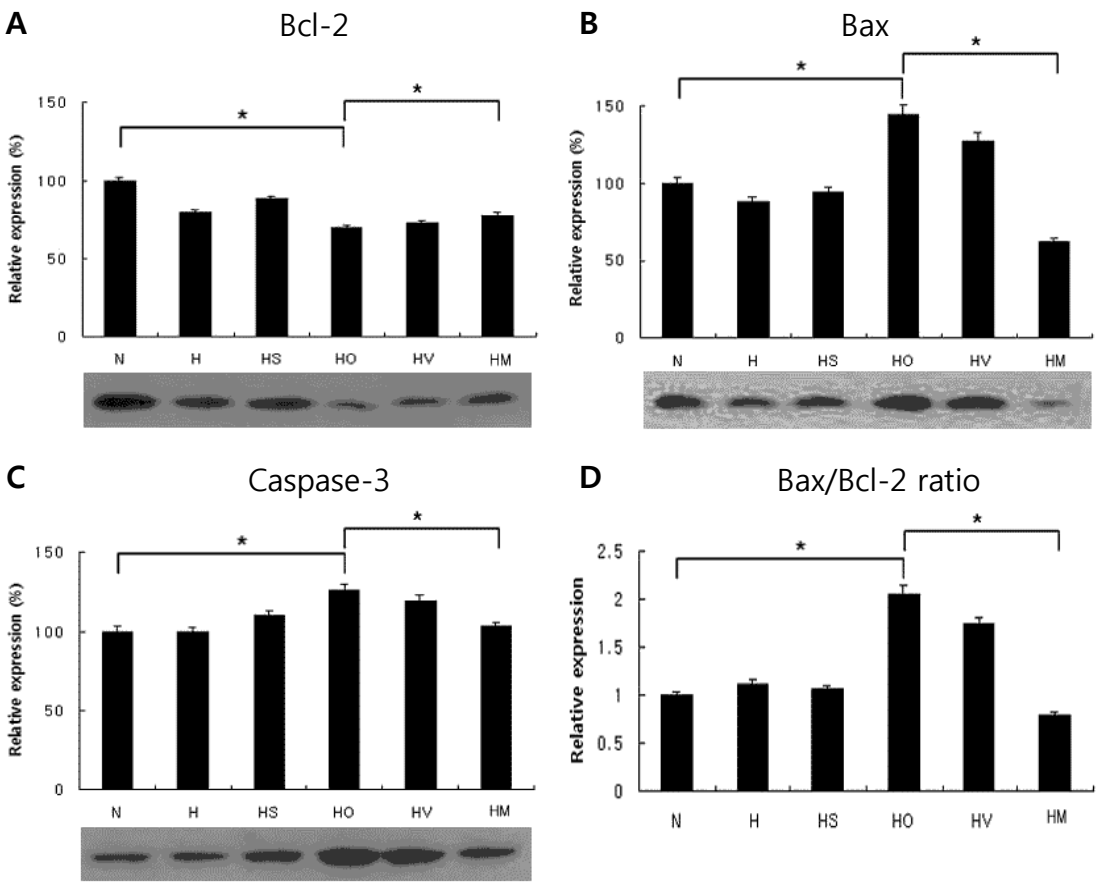

Fig. 1. Western blots of $B C l-2(A ; N, 100 \pm 2.2 ; H, 79.3 \pm 1.6 ; H S, 88.7 \pm 1.8 ; H O, 70.1 \pm 1.4 ; H V$,

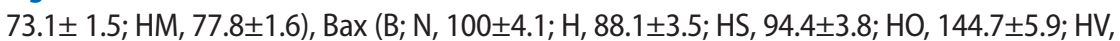

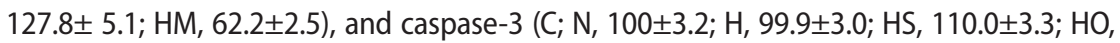
$126.0 \pm 3.8 ; \mathrm{HV}, 119.5 \pm 3.6 ; \mathrm{HM}, 103.0 \pm 3.1$ ) in the neonatal hypoxic-ischemic brain injury (in vivo) and the ratio of $\mathrm{Bax} / \mathrm{Bcl}-2$ expression (D). Data were shown as means \pm standard deviation ( $\mathrm{n}=4)$. The (2S,4R)-4-Methylglutamic Acid (SYM 2081) was administered at 10 $\mathrm{mg} / \mathrm{kg}$. N, normoxia; $\mathrm{H}$, hypoxia without operation; $\mathrm{HS}$, hypoxia with Sham operation; $\mathrm{HO}$, hypoxia with operation; HV, $\mathrm{HO}$ treated with vehicle; $\mathrm{HM}, \mathrm{HO}$ treated with $(2 \mathrm{~S}, 4 \mathrm{R})-4$ Methylglutamic Acid (SYM 2081). ${ }^{*} P<0.05$, statistically significant vs. HO. 
analysis package (SPSS Inc, Chicago, IL, USA). Examined data were assessed using the $t$-test, general lineal model, and oneway analysis of variance for statistical analysis. In each test, the data were expressed as the mean \pm standard deviation, and $P<0.05$ was accepted as statistically significant.

\section{Results}

1. Expressions of $\mathrm{BCl}-2, \mathrm{Bax}$, and caspase-3 antibodies by western blots in neonatal $\mathrm{HI}$ brain injury (in vivo)

To determine whether SYM 2081 reduced apoptosis against a hypoxic injury, western blot was used to differentiate and measure the levels of apoptosis-related proteins. Western blot analysis showed that $\mathrm{Bcl}-2$ antibody decreased significantly in the $\mathrm{HO}$ and $\mathrm{HV}$ compared to $\mathrm{N}, \mathrm{H}$, and $\mathrm{HS}$ groups, but increased in the HM compared to HO and HV groups $(P<0.05)$ (Fig. 1A). The expressions of Bax and caspase -3 antibodies and the ratio of $\mathrm{Bax} / \mathrm{Bcl}-2$ increased significantly in the $\mathrm{HO}$ and $\mathrm{HV} \mathrm{com}^{-}$ pared to N, H, and HS groups, but decreased in the HM compared to $\mathrm{HO}$ and $\mathrm{HV}$ groups $(P<0.05)$ (Fig. 1B-1D).
2. Expressions of BCl-2, Bax, and caspase-3 mRNAs by realtime PCR in neonatal $\mathrm{HI}$ brain injury (in vivo)

Real-time PCR of mRNA levels of Bcl-2, Bax, and caspase-3 was used to estimate the expression of apoptosis-related genes. The expression of Bcl-2 mRNA decreased significantly in the $\mathrm{HO}$ and $\mathrm{HV}$ compared to the $\mathrm{N}, \mathrm{H}$, and $\mathrm{HS}$ groups, but increased in the HM compared to HV group $(P<0.05)$ (Fig. 2A). The expressions of Bax and caspase $-3 \mathrm{mRNA}$ and the ratio of Bax/ $\mathrm{Bcl}-2$ increased significantly in the $\mathrm{HO}$ and $\mathrm{HV}$ compared to $\mathrm{N}$, $\mathrm{H}$, and HS groups, and decreased in the HM compared to $\mathrm{HO}$ and HV groups $(P<0.05)$ (Fig. 2B-2D). The expression of Bax was more prominent than that of $\mathrm{Bcl}-2$, resulting in a striking difference in the ratio of $\mathrm{Bax} / \mathrm{Bcl}-2$ compared with the $\mathrm{HO}$ and HM groups in the in vivo study.

3. Expressions of $\mathrm{BCl}-2$, Bax, and caspase-3 antibodies by western blots in embryonic cortical neuronal cell culture (in vitro)

Western blot analysis showed that Bcl-2 antibody decreased significantly in the Hc compared to Nc group, but it increased in the HMc compared to Hc group $(P<0.05)$ (Fig. 3A, 3B). The expressions of Bax and caspase -3 antibodies and the ratio of
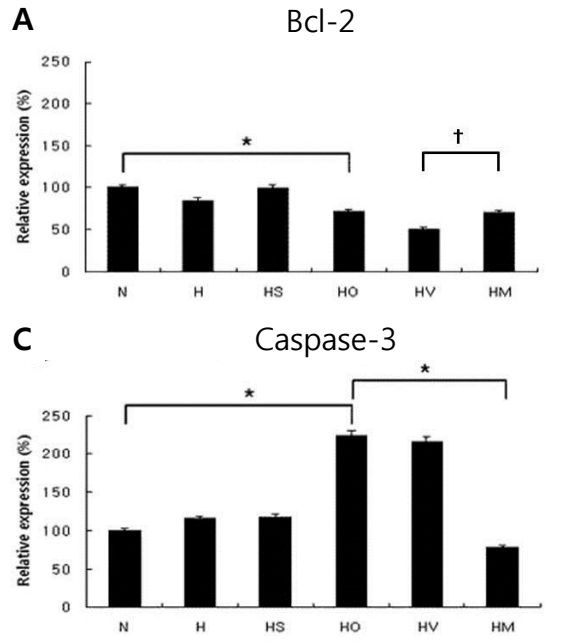

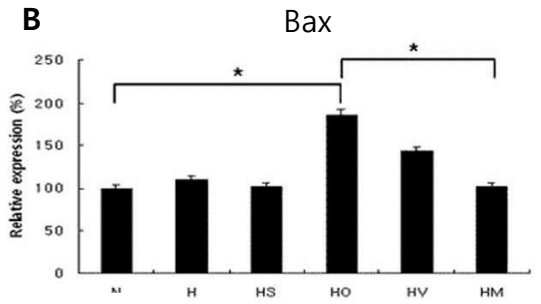

D

$\mathrm{Bax} / \mathrm{Bcl}-2$ ratio

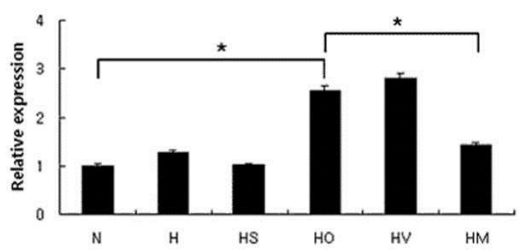

Fig. 2. Real-time PCRs of $\mathrm{BCl}-2(\mathrm{~A} ; \mathrm{N}, 100 \pm 4.5 ; \mathrm{H}, 85.3 \pm 3.4 ; \mathrm{HS}, 99.3 \pm 3.9 ; \mathrm{HO}, 72.2 \pm 2.8 ; \mathrm{HV}$,

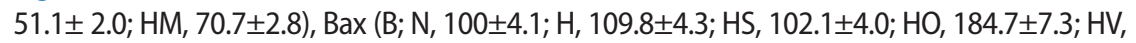

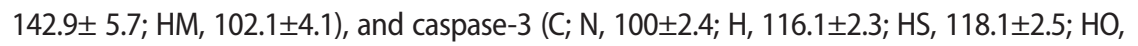
224.2 $\pm 4.4 ; \mathrm{HV}, 215.8 \pm 4.3 ; \mathrm{HM}, 78.2 \pm 1.6) \mathrm{mRNAs}$ in the neonatal hypoxic-ischemic brain injury (in vivo) and the ratio of Bax/Bcl-2 expression (D). Data were shown as means \pm standard deviation ( $\mathrm{n}=6$ ). The (2S,4R)-4-Methylglutamic Acid (SYM 2081) was administered at $10 \mathrm{mg} / \mathrm{kg}$. $\mathrm{N}$, normoxia; $\mathrm{H}$, hypoxia without operation; $\mathrm{HS}$, hypoxia with Sham operation; HO, hypoxia with operation; $\mathrm{HV}, \mathrm{HO}$ treated with vehicle; $\mathrm{HM}, \mathrm{HO}$ treated with $(2 \mathrm{~S}, 4 \mathrm{R})$-4-Methylglutamic Acid (SYM 2081). ${ }^{*} P<0.05$, statistically significant vs. $\mathrm{HO} ;{ }^{\dagger} P<0.05$, statistically significant vs. HV. 
$\mathrm{Bax} / \mathrm{Bcl}-2$ showed greater in the Hc than Nc group and lesser in the HMc than Hc group $(P<0.05)$ (Fig. 3A, 3C-3E).

\section{Expressions of $\mathrm{BCl}-2$, Bax, and caspase- 3 mRNAs by real-time} PCR in embryonic cortical neuronal cell culture (in vitro)

Real-time PCR of mRNA levels of Bcl-2, Bax, and caspase-3 was used to estimate the expression of apoptosis-related genes. The expression of $\mathrm{Bcl}-2$ decreased significantly in the Hc compared to Nc group, but increased in the HMc compared to Hc group $(P<0.05)$ (Fig. 4A). The expressions of Bax and caspase -3 mRNA and the ratio of $\mathrm{Bax} / \mathrm{Bcl}-2$ showed higher in the $\mathrm{Hc}$ than Nc group and lower in the HMc than Hc group $(P<0.05)$ (Fig. $4 \mathrm{~B}-4 \mathrm{D})$.
A

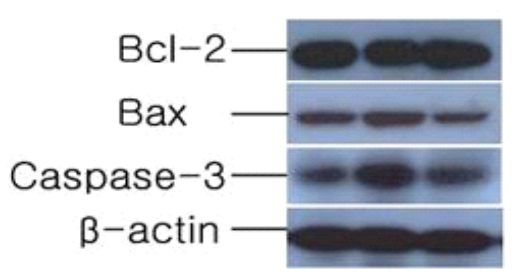

C

Bax

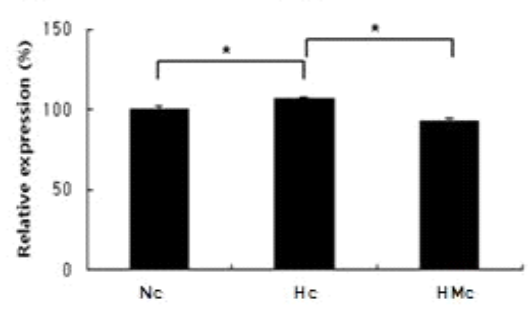

\section{Discussion}

Cell death during normal brain development occurs to remove unnecessary cells and select appropriate cells for survival and shows various cell death types such as necrosis, apoptosis, and autophagy. ${ }^{4}$ Cell death may have a significant role in neuronal injury in various pathological conditions such as neonatal $\mathrm{HIE}$, and their magnitude depend on insult-severity, time, and maturation, and be region-specific. ${ }^{7}$ Cell fate is not determined randomly or chaotically; rather cell death is strictly regulated by crosstalk between necrotic, autophagic, and apoptotic pathways. ${ }^{22}$

Although the pathologic features of HIE are predominantly necrosis, ${ }^{23}$ expression of apoptosis-related proteins is also increased in HIE. ${ }^{42}$ Although apoptosis is also considered the key mechanisms of neuronal damage in neonatal HI animal mo-

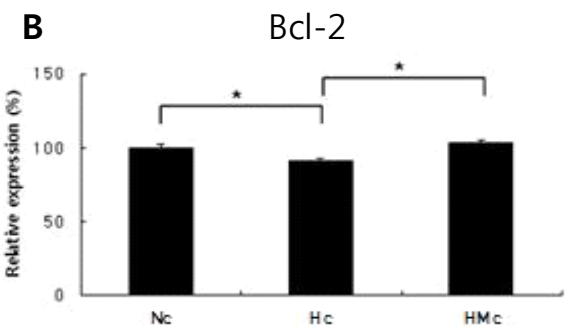

D

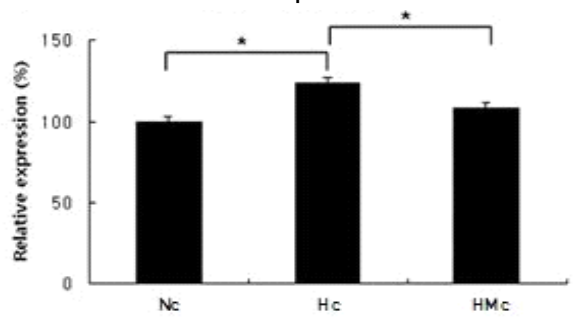

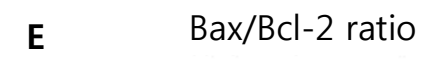

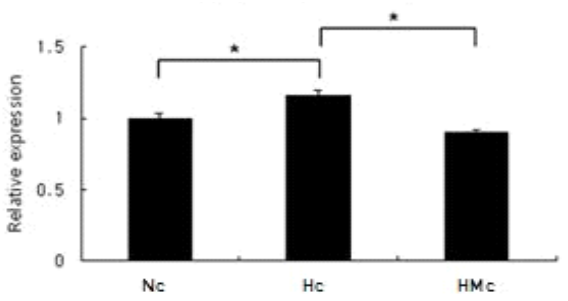

Fig. 3. Western blots (A) of $\mathrm{BCl}-2$ (B; $\mathrm{Nc}, 100 \pm 2.1 ; \mathrm{HC}, 91.3 \pm 1.98 ; \mathrm{HMc}, 103.5 \pm 2.1)$, Bax (C; Nc, $100 \pm 2.1 ; \mathrm{Hc}, 106.1 \pm 2.1 ; \mathrm{HMc}, 92.8 \pm 1.9$ ), and caspase-3 (D; Nc, 100 $\pm 3.3 ; \mathrm{Hc}, 123.5 \pm 3.7 ; \mathrm{HMC}$, $108.6 \pm 3.3$ ) in the embryonic cortical neuronal cell culture (in vitro) and the ratio of $\mathrm{Bax} / \mathrm{Bcl}-2$ expression (E). Data were shown as means \pm standard deviation $(n=4)$. The $(2 S, 4 R)-4-M e t h y l-$ glutamic Acid (SYM 2081) was administered at $10 \mu \mathrm{g} / \mathrm{mL}$. Nc, normoxia; Hc, hypoxia; HMc, hypoxia treated with (2S,4R)-4-Methylglutamic Acid (SYM 2081). ${ }^{*} P<0.05$, statistically significant vs. Hc. 

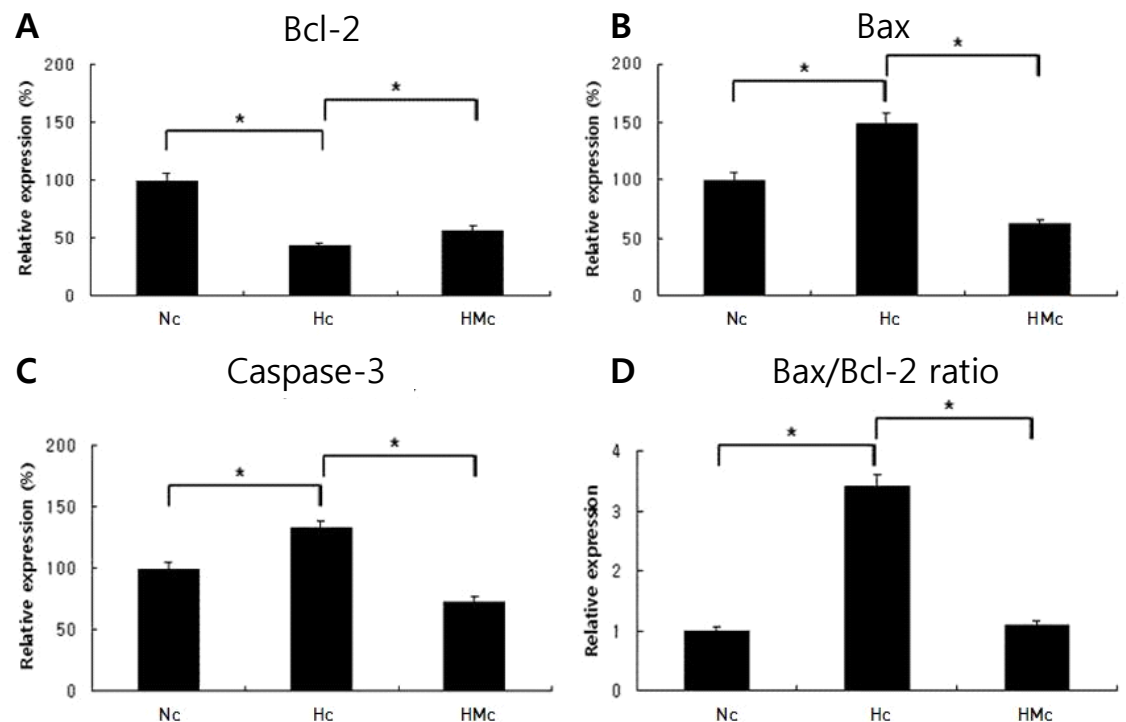

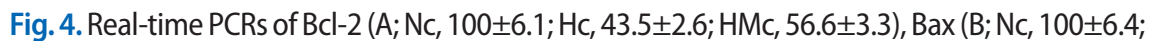

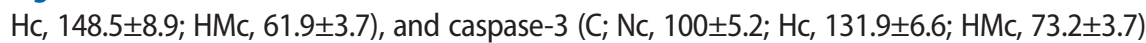
mRNAs in the embryonic cortical neuronal cell culture (in vitro) and the ratio of Bax/Bcl-2 expression (D). Data were shown as means \pm standard deviation $(n=6)$. The $(2 S, 4 R)-4-M e t h y l g l u-$ tamic Acid (SYM 2081) was administered at $10 \mu \mathrm{g} / \mathrm{mL}$. Nc, normoxia; Hc, hypoxia; HMc, hypoxia treated with (2S,4R)-4-Methylglutamic Acid (SYM 2081). ${ }^{*} P<0.05$, statistically significant vs. Hc.

dels, ${ }^{24,25}$ the pathologic features in HIE still show necrotic cell death. ${ }^{23}$ The neonatal brain has a proclivity to apoptosis, but energy failure after $\mathrm{HI}$ insult may interrupt apoptotic processes, resulting in necrosis-like pathology. Thus, agents that inhibit apoptosis in injury with mainly necrotic pathology could show neuroprotective effect. ${ }^{26}$ Indeed each cell death is closely regulated by cross-talk, and depends on species, cell type, involved brain lesion, ${ }^{27}$ degree of immaturity, severity, energy failure, and gender., ${ }^{428}$ Moreover, genetic expression that normally confers apoptosis inhibition and neuroprotection, at times can result in apoptosis exacerbation, depending on the degree of cellular energy failure; a severe cellular energy failure can result in greater necrosis or autophagy, albeit with an inhibition of apoptosis and the timing of that inhibition, over the course of the injury. ${ }^{28,29}$ The use of agents that inhibit apoptosis during severe cellular energy failure, may instead exacerbate the injury. ${ }^{30}$ Nevertheless, various antiapoptotic agents have been tried for neuroprotection because apoptosis is considered as one of the important pathogenic mechanisms involved in neonatal HIE injury.

SYM 2081 is known to be the most potent methylglutamate analog and has a methyl group located at position $4 .^{31,32}$ This methyl group position is associated with KAR affinity. ${ }^{32}$ KAR antagonists have been reported to cause toxicity, and high doses of SYM 2081 have also been reported as neurotoxic, thus showing that both activation and inhibition of KAR were neurotoxic. ${ }^{33}$ Therefore, this study used the SYM 2081 dose from a previous study showing neuroprotection. ${ }^{18}$ Treatment with systemic SYM 2081, at the dose of $10 \mathrm{mg} / \mathrm{kg}$ significantly decreased and increased expressions of pro- and anti-apoptotic markers, respectively. These results provide evidence of a neuroprotective effect of SYM 2081 against HI injury through modulating anti-apoptotic mechanisms. Because SYM 2081 is a selective GluK1 and GluK2 agonist, it also suggests an association between KAR expression and the apoptotic signaling pathway. ${ }^{32}$ SYM 2081 is known to react with KAR with high potency and to exhibit rapid desensitizing responses. ${ }^{31,34}$ However, at low concentrations, it induced desensitization, which reduces the agonist-evoked response, stabilizing the membrane and reducing depolarization..$^{34}$ Based on another study, a parenteral dose of $200 \mathrm{mg} / \mathrm{kg}$ SYM 2081 resulted $\sim 6 \mu \mathrm{M}$ steady-state brain concentration ${ }^{34}$ the lower dose concentration used in this study of $10 \mathrm{mg} / \mathrm{kg}$ may function to induce desensitization. Therefore, these might lead to reducing glutamate-induced excitotoxicity, and NMDA and AMPA receptor overactivation by 
calcium current, thereby changing predominant cell death type and leading to reduced neuronal damage. ${ }^{31}$

As mentioned previously, presynaptic KAR regulates glutamate release. ${ }^{35}$ Since GluK1 is a pharmacologically dominant subtype in heteromeric KARs, presynaptic GluK1 inhibition by SYM 2081 may reduce the release of glutamate by desensitization. ${ }^{36}$ An increase in intracellular calcium should be accompanied by glutamate release facilitated by $\mathrm{KAR}^{35}$ However, reduction of calcium influx through desensitization can also decrease glutamate release. This may also affect calcium-dependent nitric oxide synthase activation resulting in reducing cellular damage. It is presumed that inhibition of KAR with SYM 2081 may reduce depolarization, stabilize the membrane, reduce excitotoxicity by glutamate receptor overactivation and reduce presynaptic glutamate release, leading to neuroprotection. Moreover, KAR regulates glutamate release and affects the intracellular calcium level which can activate caspase-3. Therefore, SYM 2081 may affect caspase- 3 expression though modulating KAR.

The expression of apoptosis-regulating proteins such as Bax and caspase -3 was increased and $\mathrm{Bcl}-2 / \mathrm{Bax}$ ratio was decreased as the intensity of apoptosis progresses. ${ }^{25,37}$ Indeed, $\mathrm{Bcl}$ proteins and caspases are crucial proteins involved in apoptotic cell pathways and are useful marker for assessing apoptosis. ${ }^{37}$ In this study, proapoptotic markers such as caspase, BAX, and the $\mathrm{Bax} / \mathrm{Bcl}-2$ ratio increased after hypoxia exposure following LCAA ligation, consistent with other studies. ${ }^{6}$

Notably, changes in expression of Bax in the in vivo study are worthy of notice. Bax is a member of the Bcl family that increases cytochrome $\mathrm{C}$ in response to apoptotic stimuli leading to apoptosis. ${ }^{8}$ The expression of Bax can increase after HIE, and its inhibition could lead to neuroprotection effect. ${ }^{38}$ The expression of Bax changes to a subcellular distribution without little change in Bcl-2 level after insult. ${ }^{39}$ In this study, the changes in Bax expression were much more prominent than of $\mathrm{Bcl}-2$ in the $\mathrm{HO}$ group, resulting in greater changes in $\mathrm{Bax} / \mathrm{Bcl}-2$ ratio. Furthermore, with SYM 2081 treatment, the Bax expression was much more suppressed than the normoxia level, showing the pro- and anti-apoptotic balance directed toward inhibiting apoptosis. Thus, SYM 2081 could inhibit apoptosis and ameliorate neuronal injury through Bax inhibition while also increasing $\mathrm{Bcl}-2$ and reducing caspase-3 expression. ${ }^{40}$ In previous our work, ${ }^{18}$ we found that SYM 2081 reduced the volume loss after HI injury and this study showed that SYM 2081 also have neuroprotective effects through modulating apoptosis process.

The limitation of this study is results are not applicable to clinical practice because the study design didn't involve pretreating subjects before a $\mathrm{HI}$ injury because of the practically impossible nature of carrying out such an experiment. It is unclear whether SYM 2081 directly affects apoptotic signaling pathways or indirectly through inhibition of excitotoxity or mitigation of other energy failures with KAR inhibition. However, SYM 2081 may at least shift the pro- and anti-apoptotic balance toward anti-apoptosis, leading to neuroprotection.

Overall, these results suggest that KAR inhibition by SYM 2081 can affect neuroprotection by an anti-apoptotic signaling pathway notably by Bax inhibition. The inhibition of KAR by SYM 2081 may prevent cell death continuum from necrosis toward apoptosis and ameliorate cell damage by modulating apoptotic signaling pathways.

\section{Acknowledgements}

This work was supported by the grant of Research Institute of Medical Science, Catholic University of Daegu (201704).

\section{References}

1) Wu Q, Chen W, Sinha B, Tu Y, Manning S, Thomas N, et al. Neuroprotective agents for neonatal hypoxic-ischemic brain injury. Drug Discov Today 2015;20:1372-81.

2) Tagin MA, Woolcott CG, Vincer MJ, Whyte RK, Stinson DA. Hypothermia for neonatal hypoxic ischemic encephalopathy: an updated systematic review and meta-analysis. Arch Pediatr Adolesc Med 2012;166:558-66.

3) Higgins RD, Raju T, Edwards AD, Azzopardi DV, Bose CL, Clark RH, et al. Hypothermia and other treatment options for neonatal encephalopathy: an executive summary of the Eunice Kennedy Shriver NICHD workshop. J Pediatr 2011;159:851-8.e1.

4) Northington FJ, Chavez-Valdez R, Martin LJ. Neuronal cell death in neonatal hypoxia-ischemia. Ann Neurol 2011;69:743-58.

5) Yang LJ, Ma DQ, Cui H. Proteomic analysis of immature rat pups brain in response to hypoxia and ischemia challenge. Int J Clin Exp Pathol 2014; 7:4645-60.

6) Delivoria-Papadopoulos M, Ashraf QM, Ara J, Mishra OP. Nuclear mechanisms of hypoxic cerebral injury in the newborn: the role of caspases. Semin Perinatol 2008;32:334-43.

7) Yuan J, Lipinski M, Degterev A. Diversity in the mechanisms of neuronal 
cell death. Neuron 2003;40:401-13.

8) Youle RJ, Strasser A. The BCL-2 protein family: opposing activities that mediate cell death. Nat Rev Mol Cell Biol 2008;9:47-59.

9) Douglas-Escobar M, Weiss MD. Biomarkers of brain injury in the premature infant. Front Neurol 2012;3:185.

10) Sims NR, Muyderman H. Mitochondria, oxidative metabolism and cell death in stroke. Biochim Biophys Acta 2010;1802:80-91.

11) Gulyaeva NV. Non-apoptotic functions of caspase-3 in nervous tissue. Biochemistry (Mosc) 2003;68:1171-80.

12) Cheng Y, Deshmukh M, D'Costa A, Demaro JA, Gidday JM, Shah A, et al. Caspase inhibitor affords neuroprotection with delayed administration in a rat model of neonatal hypoxic-ischemic brain injury. J Clin Invest 1998;101:1992-9.

13) Lipton SA, Choi YB, Pan ZH, Lei SZ, Chen HS, Sucher NJ, et al. A redoxbased mechanism for the neuroprotective and neurodestructive effects of nitric oxide and related nitroso-compounds. Nature 1993;364: 626-32.

14) Mueller-Burke D, Koehler RC, Martin LJ. Rapid NMDA receptor phosphorylation and oxidative stress precede striatal neurodegeneration after hypoxic ischemia in newborn piglets and are attenuated with hypothermia. Int J Dev Neurosci 2008;26:67-76.

15) Benveniste M, Wilhelm J, Dingledine RJ, Mott DD. Subunit-dependent modulation of kainate receptors by muscarinic acetylcholine receptors. Brain Res 2010;1352:61-9.

16) Lerma J, Marques JM. Kainate receptors in health and disease. Neuron 2013:80:292-311.

17) Sihra TS, Flores G, Rodríguez-Moreno A. Kainate receptors: multiple roles in neuronal plasticity. Neuroscientist 2014;20:29-43.

18) Lee JH, Lee EJ, Jang $Y Y$, Jeong JE, Chung HL, Kim WT. Neuroprotective effects of SYM 2081, targeting kainate receptors in the neonatal hypoxic-ischemic brain injury. Perinatology 2016;27:149-57.

19) Rice JE 3rd, Vannucci RC, Brierley JB. The influence of immaturity on hypoxic-ischemic brain damage in the rat. Ann Neurol 1981;9:131-41.

20) Brewer GJ. Isolation and culture of adult rat hippocampal neurons. J Neurosci Methods 1997;71:143-55.

21) Livak KJ, Schmittgen TD. Analysis of relative gene expression data using real-time quantitative PCR and the 2(-Delta Delta C(T)) method. Methods 2001;25:402-8.

22) Proskuryakov SY, Konoplyannikov AG, Gabai VL. Necrosis: a specific form of programmed cell death? Exp Cell Res 2003;283:1-16.

23) Carloni S, Carnevali A, Cimino M, Balduini W. Extended role of necrotic cell death after hypoxia-ischemia-induced neurodegeneration in the neonatal rat. Neurobiol Dis 2007;27:354-61.

24) Kiraz Y, Adan A, Kartal Yandim M, Baran Y. Major apoptotic mechanisms and genes involved in apoptosis. Tumour Biol 2016;37:8471-86.

25) Kajta M. Apoptosis in the central nervous system: mechanisms and protective strategies. Pol J Pharmacol 2004;56:689-700.

26) Arthur DB, Georgi S, Akassoglou K, Insel PA. Inhibition of apoptosis by P2Y2 receptor activation: novel pathways for neuronal survival. J Neurosci 2006;26:3798-804.
27) Natale JE, Cheng Y, Martin LJ. Thalamic neuron apoptosis emerges rapidly after cortical damage in immature mice. Neuroscience 2002; 112: 665-76.

28) Northington FJ, Zelaya ME, O'Riordan DP, Blomgren K, Flock DL, Hagberg $\mathrm{H}$, et al. Failure to complete apoptosis following neonatal hypoxia-ischemia manifests as "continuum" phenotype of cell death and occurs with multiple manifestations of mitochondrial dysfunction in rodent forebrain. Neuroscience 2007;149:822-33.

29) Chalak LF, Sánchez PJ, Adams-Huet B, Laptook AR, Heyne RJ, Rosenfeld CR. Biomarkers for severity of neonatal hypoxic-ischemic encephalopathy and outcomes in newborns receiving hypothermia therapy. Pediatr 2014;164:468-74.e1.

30) Carloni S, Buonocore G, Balduini W. Protective role of autophagy in neonatal hypoxia-ischemia induced brain injury. Neurobiol Dis 2008;32: 329-39.

31) Jones KA, Wilding TJ, Huettner JE, Costa AM. Desensitization of kainate receptors by kainate, glutamate and diastereomers of 4-methylglutamate. Neuropharmacology 1997;36:853-63.

32) Donevan SD, Beg A, Gunther JM, Twyman RE. The methylglutamate, SYM 2081, is a potent and highly selective agonist at kainate receptors. J Pharmacol Exp Ther 1998;285:539-45.

33) Carver JM, Mansson PE, Cortes-Burgos L, Shu J, Zhou LM, Howe JR, et al. Cytotoxic effects of kainate ligands on HEK cell lines expressing recombinant kainate receptors. Brain Res 1996;720:69-74.

34) Zhou LM, Gu ZQ, Costa AM, Yamada KA, Mansson PE, Giordano T, et al (2S,4R)-4-methylglutamic acid (SYM 2081): a selective, high-affinity ligand for kainate receptors. J Pharmacol Exp Ther 1997;280:422-7.

35) Andrade-Talavera Y, Duque-Feria P, Negrete-Díaz JV, Sihra TS, Flores G, Rodríguez-Moreno A. Presynaptic kainate receptor-mediated facilitation of glutamate release involves Ca2+-calmodulin at mossy fiberCA3 synapses. J Neurochem 2012;122:891-9.

36) Alt A, Weiss B, Ogden AM, Knauss JL, Oler J, Ho K, et al. Pharmacological characterization of glutamatergic agonists and antagonists at recombinant human homomeric and heteromeric kainate receptors in vitro. Neuropharmacology 2004;46:793-806.

37) Hernández-Jiménez $M$, Sacristán $S$, Morales $C$, García-Villanueva $M$ García-Fernández E, Alcázar A, et al. Apoptosis-related proteins are potential markers of neonatal hypoxic-ischemic encephalopathy (HIE) injury. Neurosci Lett 2014;558:143-8.

38) Sun MY, Cui KJ, Yu MM, Zhang H, Peng XL, Jiang H. Bax inhibiting peptide reduces apoptosis in neonatal rat hypoxic-ischemic brain damage. Int J Clin Exp Pathol 2015;8:14701-8.

39) Northington FJ, Ferriero DM, Flock DL, Martin LJ. Delayed neurodegeneration in neonatal rat thalamus after hypoxia-ischemia is apoptosis. $J$ Neurosci 2001;21:1931-8.

40) Blomgren $K$, Zhu C, Wang X, Karlsson JO, Leverin AL, Bahr BA, et al. Synergistic activation of caspase-3 by m-calpain after neonatal hypoxia-ischemia: a mechanism of "pathological apoptosis"? J Bio Chem 2001;276:10191-8. 